\title{
Permanent wilt point from two methods for different combinations of citrus rootstock
}

\author{
Rivani Oliveira Ferreira ${ }^{1^{*}}$ (D) Luciano da Silva Souza ${ }^{2}$ \\ Marilza Neves do Nascimento ${ }^{1}$ Felipe Gomes Frederico da Silveira ${ }^{2}$
}

\begin{abstract}
${ }^{1}$ Departamento de Ciências Biológicas, Universidade Estadual de Feira de Santana (UEFS), 44036900, Feira de Santana, BA, Brasil. E-mail: rivaniserrinha@yahoo.com.br. "Corresponding author.

${ }^{2}$ Departmento de Ciências do Solo, Universidade Federal do Recôncavo da Bahia (UFRB), Cruz das Almas, BA, Brasil.

ABSTRACT: Considering that water is extremely important in agricultural production, but with restricted availability in some Brazilian regions, this research sought to identify the water limit for the rootstocks: Cleóptra tangerine (Citrus reshni hort. Ex Tan), Volkamer lime (Citrus Volkameriano Pasquale), Citrandarin 'indio'(TSK X TRENG 256), Santa Cruz Rangpur lime (Citrus $\times$ limonia) and Sunki Tropical tangerine (Citrus sunki HORT. EX TAN) grafted orange 'Pera'(Citrus sinensis), obtained by two methods: the traditional method of determining the permanent wilting point described by SHANTZ \& BRIGGS (1912) recovery of plants with saturated environment and by irrigating recovery method. The experimental design used was in a completely randomized design with four replications totaling 20 experimental plots. It was verified that the rootstocks Cravo Santa Cruz lemon and Volkamerian lemon were the most resistant in initial conditions of water restriction, evaluated by the method of BRIGGS \& SHANTZ (1912), with recording of humidity of 0.0488 and 0.0489 respectively. Under more severe conditions of water restriction, determined by the irrigation method, Volkamerian lemon presented the highest resistance, with a humidity of 0.0371 .

Key words: permanent wilting point, water déficit, hydrical stress.
\end{abstract}

Ponto de murcha permanete a partir de dois métodos para diferentes combinações copa porta-enxerto de citros

RESUMO: Considerando que a água é extremamente importante na produção agrícola, mas com restrita disponibilidade em algumas regiões brasileiras, é que esse trabalho buscou identificar o limite hídrico inferior para os porta-enxertos: tangerina Cleóptra (Citrus reshni hort. Ex Tan), limão Volkameriano (Citrus Volkameriano Pasquale), citrandarin 'Indio'-TSK X TRENG 256, limão Cravo Santa Cruz (Citrus $\times$ limonia) e tangerina Sunki Tropical (Citrus sunki HORT. EX TAN) enxertadas em laranja 'Pêra'(Citrus sinensis), obtidos por dois métodos: o método tradicional de determinação do ponto de murchamento permanente descrito por BRIGGS \& SHANTZ (1912) com recuperação das plantas em ambiente saturado e o método de recuperação por rega. O delineamento experimental utilizado foi o inteiramente casualizado, com quatro repetições, totalizando 20 parcelas experimentais. Verificou-se que os porta-enxertos limão Cravo Santa Cruz e o limão Volkameriano foram os mais resistentes em condições iniciais de restrição hídrica, avaliado pelo método de BRIGGS \& SHANTZ (1912), com registro das umidades de 0,0488 e 0,0489, respectivamente. Em condições mais severas de restrição hídrica, determinado pelo método de rega, o limão Volkameriano foi o que apresentou maior resistência, com a umidade de 0,0371.

Palavras-chave: ponto de murchamento permanente, déficit hidrico, estresse hídrico.

\section{INTRODUCTION}

Water is the most important factor limiting agricultural productivity, since water deficit can influence metabolism (CRUZ et al., 2005), the structure and transport in plants (BIANCHI et al., 2016), promoting morphophysiological disorders crops (FERRAZ et al., 2011). Also, the shortage of water is a phenomenon occurring registered in large acreages (NOGUEIRA et al., 2001).

It is considered as water available to plants, that present between the field capacity (FC) and permanent wilting point (PWP) (SOUZA et al., 2002). The field capacity is the amount of water held by the soil after the excess is drained movement with marked decrease (VEIHMEYER \& HENDRICKSON, 1949). The PWP is the minimum limit of Soil Water Content which the plants to lose turgor and wilted not recover to be transferred to the dark environment and saturated with water (BRIGGS \& SHANTZ, 1912).

These limits are influenced by soil physical properties, and may differ between crops in response to existing adaptation mechanisms in each species (SALVESTRO et al., 2013). From several studies it was established tension of $1.5 \mathrm{MPa}$ as water available limit the PWP (COELHO et al., 2014).

However, the physiological wilting point of the crops does not always correspond to this value, since each species respond differently to such 
a situation (ALVES, 2010), being the most suitable to define the specific point of physiological wilting for each crop (BRIGGS \& SHANTZ, 1912), thus ensuring greater efficiency in the management of irrigation projects, as well as in choosing the most efficient species in water use (KLEIN et al., 2010).

The choice of species more resistant and efficient use of water is the most suitable alternative for agriculture in arid and semi-arid environments, as the great periods of drought facing, reaching extreme scarcity at some time of the year (SILVA et al., 2009).

In situations of water scarcity, plants can be affected by that describes how stress conceptualized phenomenon while a deviation from the ideal conditions for life, capable of causing changes and responses at different levels in the body, which may be a reversible principle or become permanent depending on the intensity or duration of the phenomenon (LARCHER, 2000).

According BIANCHI et al. (2016), stress has four phases: initial phase, known as the alarm reaction; resistance or restitution phase, wherein the plant uses mechanisms to cope with the situation to the maximum; final phase or stage of exhaustion when the resistance mechanism are no longer able to respond and may lead to plant collapse; and the regeneration phase, when stress is suspended and the plant may or may not recover fully or partially.

Thus, it is likely that the PWP not always represent the final stage of stress exhaustion, but the regeneration phase, when access to water again. The citrus industry is one of the agricultural activities with great importance in the Brazilian economy, bequeathing to Brazil the title of world's largest producer of this crop (SOARES et al., 2015). However, one of the deficiencies in this activity is the use of few combinations of canopy cover and rootstock, a factor that exposes them to pests attack and the occurrence of abiotic stresses, among these, water stress (SCHINOR et al., 2006).

Thus, it is believed that when reaching PWP by the traditional method proposed by Briggs \& Shantz, the plants are still able to recover when access to water in the soil, being this the condition similar to that experienced by the plants in the field, in periods of drought, when they are submitted to the water deficit extending until the new rainy season Thus, it was sought to identify the moisture limit in the soil at the physiological wilt point by the conventional method, as well as the moisture limit for the physiological PWP obtained by irrigation, for combinations of 'Pêra' orange with five citrus rootstock.

\section{MATERIALS AND METHODS}

The experiment was conducted in a greenhouse in the experimental unit belonging to the Universidade Estadual de Feira de Santana, Bahia, Latitude: 1216 '00 "S and Longitude: 38 58' 00" W, starting in January 2017 and ending in June of the same year.

Were analyzed the rootstocks: Cleóptra tangerine (Citrus reshni hort. Ex Tan), Volkamer lime (Citrus Volkameriano Pasquale), citrandarin 'Indio' (TSK X TRENG 256), Santa Cruz Rangpur lime (Citrus $\times$ limonia) and Sunki Tropical tangerine (Citrus sunki HORT. EX TAN) grafted orange 'Pera' (Citrus sinensis) in a completely randomized design with four replications totaling 20 experimental plots.

The seedlings were produced and grafting by Embrapa Mandioca e Fruticultura growing, located in Cruz das Almas -BA city. After grafting the plants were transplanted to pots with $50 \mathrm{~cm}$ tall and $20 \mathrm{~cm}$ diameter, it was filled with $14 \mathrm{~kg}$ of substrate, produced on the experimental unit, having the following chemical characteristics: $\mathrm{pH} 6.5 ; \mathrm{P} 9.73$ $\mathrm{mg} / \mathrm{dm}^{3} ; \mathrm{K} 15.64 \mathrm{mg} / \mathrm{dm}^{3} ; \mathrm{Na} 23.0 \mathrm{mg} / \mathrm{dm}^{3} ; \mathrm{Ca}^{2+}$ $7.0 \mathrm{cmol}(\mathrm{c}) / \mathrm{dm}^{3} ; \mathrm{Mg}^{2+} 1.8 \mathrm{cmol}(\mathrm{c}) / \mathrm{dm}^{3} ; \mathrm{Al}^{3+} 0.0$ $\mathrm{cmol}(\mathrm{c}) / \mathrm{dm}^{3} ; \mathrm{H}+\mathrm{Al} 0.7 \mathrm{cmol}$ (c) $/ \mathrm{dm}^{3} ; \mathrm{MO} 1.82 \%$.

The experiment started one month after the transplant, in which the plants were watered with $900 \mathrm{~mL}$ of water, the containers were sealed with aluminum foil, covered with film paper. From that moment the plants were not watered until reaching the permanent wilting point.

As the plants showed wilting signal, the pots were moved to the end of the day a dark room with relative humidity close to $100 \%$ for 48 hours, it is seen plants already developed.

When completing the period, we observed the return or not of turgidity of each plant, adopting the criteria that if at least one sheet to recover, the vessel then returned to the greenhouse, remaining without irrigation. This succession was not until the final return of turgidity, assuming then as a traditional physiological permanent wilting point (TPPWP). Soil samples were collected (without roots), weighed on a precision scale and taken to the drying oven at $105{ }^{\circ} \mathrm{C}$ for 48 hours and weighed again to determine moisture in the sample gravimetric basis. From the gravimetric water content in the soil samples for each evaluated plant, the moisture corresponding to the physiological permanent wilting point (TPPWP) of the crop was determined.

After reaching the traditional method (TPPWP) by BRIGGS \& SHANTZ (1912) initiated 
to check that wilt point from the access Soil Water Content. Thus, the same plants were watered again with $900 \mathrm{~mL}$ suspending access to water again, and awaiting the physiological permanent wilting point by watering (PPWPW). At that time a new soil sample was collected to obtain the water content at the physiological permanent wilting point by watering. The criterion used for the return was the recovery of the plants or even the emission of new leaves within a period of three days.

Plants that were recovering were held without access water to reach the water limit and no definitive return. Before being watered again, new soil sample was collected up to obtain the water content in point of permanent wilting of reference - PWPr.

To determine the vase capacity, it was built a water retention curve in the soil, using Richards system, depending on the moisture content in saturated samples obtained and subjected to pressures of $-1,-33,-100,-500,-1500 \mathrm{kPa}$. For this we used a soil sample collected in rings, saturated capillary, for a period of 24 hours and placed in the extractor apparatus porous plates Richards.

After equilibration, the samples were weighed and oven dried at $105^{\circ} \mathrm{C}$, to obtain the corresponding moisture at each pressure. The data were fitted to the mathematical model proposed by VAN GENUCHTEN (1980):

$\theta=\theta_{r}+\frac{\theta_{S}-\theta_{r}}{\left[1+\left(\left|\alpha \phi_{m}\right|\right)^{n}\right]^{m}}$

On what, $\theta$ is the volumetric moisture, $\phi$ is the potential; $\theta$ s and $\theta \mathrm{r}$ respectively, residual moisture and gravimetric saturation, and $n, m, \alpha$ are tuning parameters.
From the water retention curve (Figure 1) and using the equation 2, it was possible to find the matric potential for each combination canopy rootstock in both water limits analyzed:

$\phi_{m}=\frac{\left[\left(\frac{\theta_{s}-\theta_{r}}{\theta-\theta_{r}}-1\right)^{\frac{1}{m}}\right]^{\frac{1}{n}}}{\alpha}$

The variables analyzed were: moisture at the permanent wilting point by the classical and irrigation method and the days until reaching the permanent wilting point. Results were subjected to ANOVA and means were compared by SCOTTKNOTT TEST (1974) at 5\% probability, using the statistical program Sisvar.

\section{RESULTS AND DISCUSSION}

Results for the water boundary at the traditional physiological permanent wilting point (Table 1) showed that the rootstocks Volkamer lime (VL) and Santa Cruz Rangpur lime (SCRL) were not statistically different from each other, with the lower water content in this condition, followed by rootstock Cleopatra tangerine (CT) with intermediate values. The higher humidity values that permanent wilting point were observed in citrandarin Indian (TSK $\mathrm{X}$ TRENG 256) (CI) and tropical sunki tangerine (TSM), which did not statistically differ from each other. These results show a higher capacity of the LV and LCSC rootstocks to absorb the water more strongly retained in the soil in relation to the other rootstocks analyzed.

The transformation of these water content values in matric potential indicated that in the

Table 1 - Average humidity values and days to the traditional permanent wilting point and watering on different rootstocks of citrus in orange canopy 'Pera'.

\begin{tabular}{|c|c|c|c|c|c|}
\hline \multirow[t]{2}{*}{ Variables } & \multicolumn{5}{|c|}{ 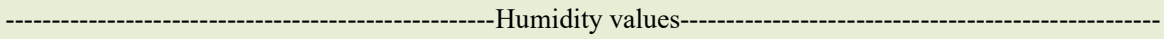 } \\
\hline & CT & VL & $\mathrm{CI}$ & SCRL & TST \\
\hline $\operatorname{MPWP}\left(\mathrm{m}^{3} \mathrm{~m}^{3}\right)$ & $0.0571 \mathrm{~b}$ & $0.0489 \mathrm{c}$ & $0.0878 \mathrm{a}$ & $0.0488 \mathrm{c}$ & $0.0888 \mathrm{a}$ \\
\hline \multirow[t]{2}{*}{ H.Irrigation $\left(\mathrm{m}^{3} \mathrm{~m}^{3}\right)$} & $0.0529 \mathrm{~b}$ & $0.0371 \mathrm{~d}$ & $0.0632 \mathrm{a}$ & $0.0426 \mathrm{c}$ & $0.0666 \mathrm{a}$ \\
\hline & ------------ & -------------- & ------Days & ---------. & ---------- \\
\hline TPPWP & $50 \mathrm{bA}$ & $57 \mathrm{aA}$ & $37 \mathrm{cA}$ & $56 \mathrm{aA}$ & $33 \mathrm{cA}$ \\
\hline PPWPI & $81 \mathrm{cB}$ & $101 \mathrm{aB}$ & $87 \mathrm{bB}$ & $90 \mathrm{bB}$ & $86 \mathrm{bB}$ \\
\hline
\end{tabular}

Lowercase letters in the same line and capital letters in the same column do not differ statistically from each other by Skott-Knott test (P $<0.05)$. CT - Cleopatra tangerine; LV - Volkamer lime; CI - citrandarin 'Indio' -TSK X TRENG 256; SCRL - Santa Cruz Rangpur lime; TST - tropical Sunki tangerine; - TPPWP - Humidity in the traditional physiological permanent wilting poin; PPWPI - humidity in the physiological permanent wilting point by irrigation. 


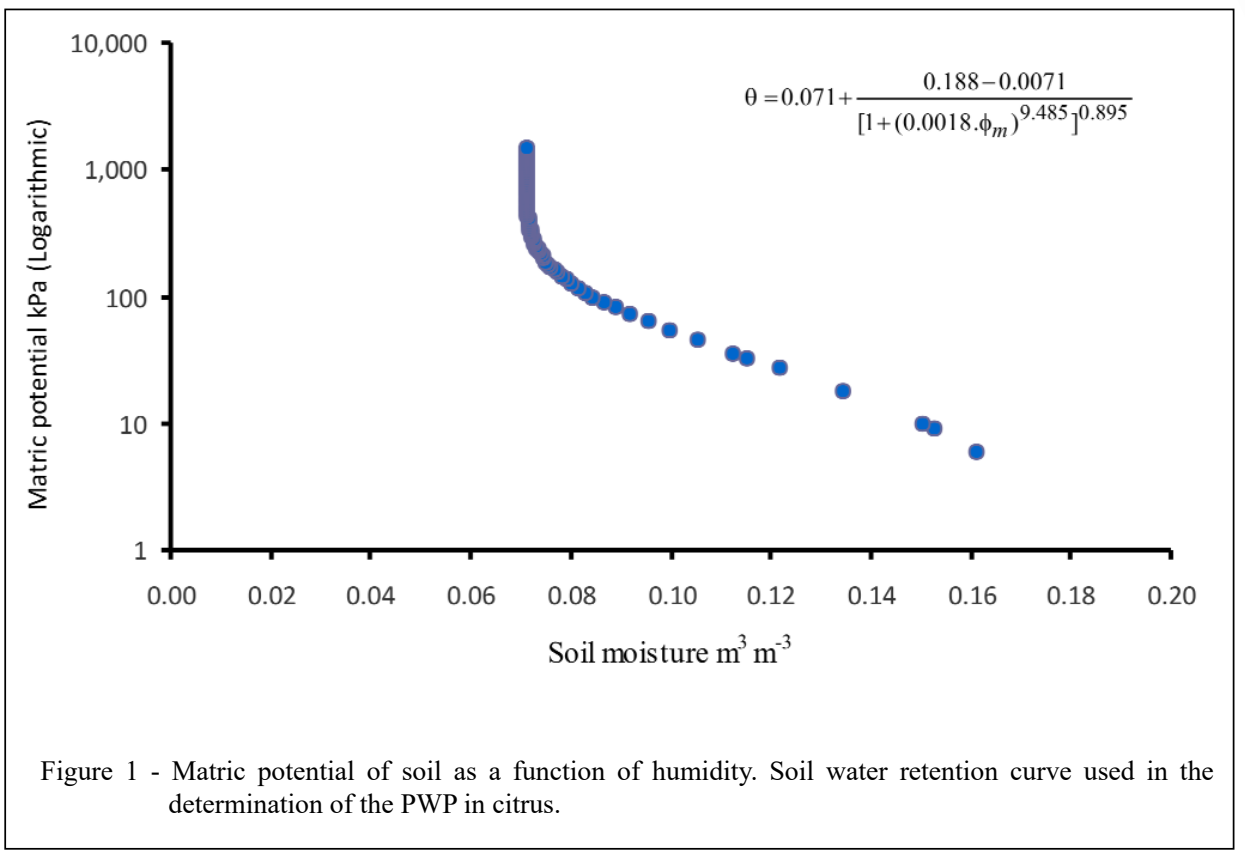

exception of Indian rootstocks and tropical sunki tangerine, the other rootstocks found with lower potential to $-1.5 \mathrm{MPa}$, potential conventionally used for PWP, that is, they had withstood a soil water potential lower than established for crops. SOUZA \& PAIVA (2001), when analyzing the matric potential of soils of the Coastal Board in the city of SapeaçuBA, verified that the citrus plants cultivated in these soils could survive to potentials less than $-1.5 \mathrm{MPa}$, concluding that this crop presents PWP at potentials lower than $-1.5 \mathrm{MPa}$, soon, that the PWP reference value does not apply to that crop and is actually lower (more negative) to that limit.

Results of TPPWP indicated that the rootstock Volkamer lime (VL) and Santa Cruz rangpur lime (SCRL) are more resilient in water deficit conditions. FERNANDES et al. (2011) reported similar results when analyzing different rootstocks subjected to salt stress by checking the rootstock Volkamer lime was the least sensitive to such a situation.

CINTRA et al. (2000), to perform the water balance of a citrus area, also noted that the rootstock Santa Cruz rangpur lime had the lowest amount of evapotranspiration from the others present in the area, indicating that it is one of the mechanisms of its adaptation to tolerate water deficit.

Results for the moisture limit at the point of permanent physiological wilting by irrigation (Table 1) indicated that the rootstock Volkamer lime was that resisted the lowest humidity value on the ground, this being the point where the Soil Water Content, the plant has not recovered. The value for the rootstock Volkamer lime was statistically different from the others, suggesting that it was the more resistant rootstock in conditions of water deficit, among the evaluated.

When comparing the values for the two given water limits (Figure 2), it was reported that the Indian rootstocks and tropical sunki tangerine were those with the biggest difference between the moisture in the traditional PWP and PWP for irrigation, with percentages around $28 \%$ and $25 \%$, respectively (Figure 2).

These results show that to achieve the traditional PWP, the plants are still able to recover when access to Soil Water Content and can correlate these situations with the different phases described by BIANCHI, et al. (2016) for conditions of stress. 


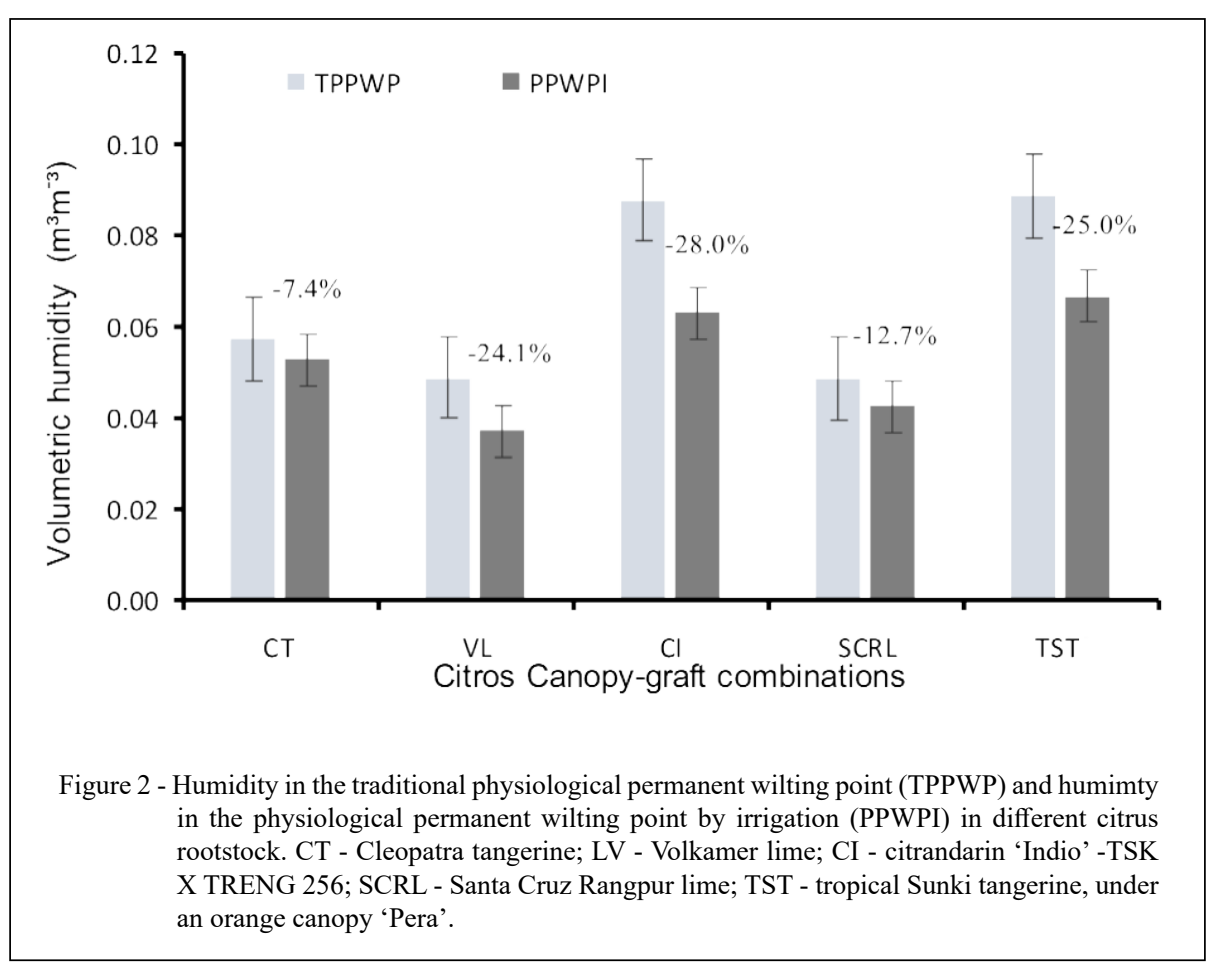

In the first limit of permanent physiological wilt by the traditional method the plants are still able to regenerate, by suspending the stressor (drought), while at the second physiological permanent wilt limit determined by the irrigation method, even with the suspension of stress, plants are no longer able to recover, may coincide with the phase of exhaustion, that is, at the second limit established by the irrigation method, plants may have lost their regeneration capacity due to the prolonged water deficit to which they were submitted.

The time to reach the TPPWP (Table 1) followed soil humidity results (Table 1) and rootstocks which had the lower water content in this condition, leading them more days to reach such a situation. For the traditional method, the mean days until reaching TPPWP ranged from 33 to 57 days. However, for PPWPW moisture, the Cleopatra tangerine grafted seed was the first to reach this point; although, it did not present the highest soil moisture upon reaching TPPWP.

The graft holder Volkamer lime was what took more days to reach the PPWPI, differing from the other rootstocks. The result indicated that this rootstock is possibly more resistant to the conditions of prolonged water deficit, factor that may be associated to physiological mechanisms of greater efficiency in the use of water and greater capacity and water absorption to very low potential potentials. By analyzing the soil water potential in Coastal board crops with citrus, SOUZA \& PAIVA (2001) observed that the citrus plants were able to withstand more than four months with soil matric potential of less than -1.5 MPa.

COELHO et al. (2014) also values lower than -1.5 MPa for the PMP in cowpea bean and concluded that this would result in increased availability of water to the crop this could mean increased tolerance to drought species.

\section{CONCLUSIONS}

There was a difference between the values of humidity at the permanent wilting point established by the traditional method and the irrigation method, indicating that when reaching the first point of much, plants are still able to regenerate when accessing water. The lowest values of moisture were observed in the rootstocks Santa Cruz Rangpur lime and Volkamerian lemon, indicating that they are the most resistant to water deficit.

\section{ACKNOWLEDGEMENTS}

This study was financed in part by the Coordenação de Aperfeiçoamento de Pessoal de Nível Superior - Brasil (CAPES) - Finance Code 001.

Ciência Rural, v.50, n.1, 2020. 
Research work supported by financial resources of the project "Water balance in cohesive soil of Coastal Tablelands culivated with orange 'Pêra' on different rootstocks, in two orchard implanted systems", funded by the National Research Council, Brazil, Process 446239/2014-3.

\section{DECLARATION OF CONFLICTI OF INTERESTS}

The authors declare no conflict of interests.

\section{AUTHORS' CONTRIBUTIONS}

The authors contributed equally to the manuscript.

\section{REFERENCES}

ALVES, W.W. A. et al. Métodos de determinação e níveis de água disponível no solo: efeito sobre a cultura do algodoeiro herbáceo. Revista Caatinga, v.23, p.91-94. 2010. Available from: <http:// periodicos.ufersa.edu.br/index.php/sistema $>$. Accessed: Jan. 20, 2018.

BIANCHI, G. et al. Adaptation of Plants to deficit Hydride (pdf). Acta Iguazu, v.5, n.4, p.15-32. 2016. Available from: <https:// www.researchgate.net/publication/312119183_Adaptacao_das Plantas_ao_Deficit_Hidrico>.Accessed: Jan. 15, 2018.

BRIGGS, L.J; SHANTZ, H.L. The wilting coefficient for different plants and its indirect determination. Washington $\mathrm{DC}$ : Department of Agriculture, Bureau of Plant Industries, Bulletin No. 30, 83, p.1912. Available from: <https://doi.org/10.5962/bhl. title.64958>. Accessed: Sept. 03, 2016.

SOUZA, C. C. de et al. Evaluation of available water determination methods in cotton cultivated soil. Pesq. agropec. bras., v.37, n.3, p.337-341, mar. 2002. Available from: <http://www.scielo.br/pdf/ pab/v37n3/9008.pdf>. Accessed: Oct. 30, 2019.

CINTRA, F. L. D. etal. Soil water balance for citrus rootstocks in coastal board ecosystem. Journal of Agricultural and Environmental Engineering, v.4, n.1, p.23-28. 2000. Available from: $<\mathrm{http} / / \mathrm{www}$. agriambi.com.br/revista/v4n1/023.pdf> . Accessed: Jan. 20, 2018. doi: $10.1590 / \mathrm{S} 1415-43662000000100005$

COELHO, J. B. et al. Physiological permanent wilting point and osmotic potential of cowpea cultivated in salinized soils. Revista Brasileira de Engenharia Agrícola. Environmental, v.18, n.7, p.708-713, 2014. Available from: $<$ http://www.scielo.br/pdf/rbeaa/ v18n7/v18n07a06.pdf $>$. Accessed: Jan. 23, 2018. doi: 10.1590/ S1415-43662014000700006.

CRUZ, A. C. R. et al. Actual evapotranspiration of an orange crop in production on a Red-Yellow Latosol. Revista Brasileira de Ciência do Solo, 29: 659-668, 2005. Available from: $<$ http://www. scielo.br/pdf/rbcs/v29n5/27877.pdf > . Accessed: Jan. 22, 2018. doi: 10.1590/S0100-06832005000500001.

FERNANDES, P. D. et al. Growth of hybrids and rootstock varieties of citrus under salinity. Maringá, v.33, n.2, p.259-267, 2011. Available from: <https://ainfo.cnptia.embrapa.br/digital/ bitstream/item/37674/1/Id27761.pdf> Accessed: Jan. 18, 2018. DOI: $10.4025 /$ actasciagron.v33i2.5582.

FERRAZ, R. L. S. et al. Morphophysiological aspects, yield and water use efficiency of melon "Gália" in protected environment. Revista Ciência Agronômica, v.42, no.4, p.957964, 2011. Available from: <http://www.scielo.br/pdf/rca/v42n4/ a18v42n4.pdf $>$. Accessed: Feb. 14, 2018. doi: 10.1590/S180666902011000400018 .

KLEIN, V. A. et al. Soil texture and estimated water content at permanent wilting point with Psychrometer. Ciência Rural, v.40, n.7, p.1550-1556, 2010. Available from: <http://www.scielo. br/pdf/cr/v40n7/a645cr2720.pdf >. Access: Jan. 22, 2018. doi: 10.1590/S0103-84782010005000110.

LARCHER, W. Plant ecology. San Carlos: RiMa Artwork and Text, 2000. 531p.

NOGUEIRA, R. J. et al. Changes in leaf vapor diffusion resistance and water relations in acerola plants subjected to water deficit. Revista Brasileira de Fisiologia Vegetal. Vol.13 no.1 Lavras, 2001. Available from: <http://www.scielo.br/pdf/\%0D/rbfv/ v13n1/9275.pdf $>$. Accessed: May, 06, 2018.

SALVESTRO, A. C. et al. Permanent wilting point of soybean in Rhodic ferralsols with and without incorporation biodegradable organic residue and physiological monitoring in relation to the behavior of moisture. Journal of Food, Agriculture and Environmen, v.11, n.3-4, p. 1248-1252, 2013. Available from: $\quad<$ https://www.researchgate.net/publication/285774280>. Accessed: Jan. 18, 2018.

SCOTT, A.; KNOTT, M. Cluster-analysis method for grouping means in analysis of variance. Biometrics., v.30, n.3, p.507-512, 1974. Available from: <https://www.jstor.org/stable/2529204>. Accessed: Nov. 18, 2017. doi: 10.2307/2529204.

SCHINOR, E. H. Organogenesis in vitro from different regions of the epicotyl Citrus sp. Journal of Fruit Culture, v.28, p.463-466, 2006. Available from: <http://www.scielo.br/pdf/rbf/v28n3/27. pdf $>$. Accessed from: Jan. 22, 2018. doi: 10.1590/ S010029452006000300027.

SILVA, E. C. et al. Stomatal changes induced by intermittent drought in four umbu tree genotypes. Brazilian Journal of Plant Physiology, v.21, no.1, p.33-42, 2009. Available from: <http:// www.scielo.br/pdf/bjpp/v21n1/a05v21n1.pdf>. Accessed: Mar. 03, 2018. doi: 10.1590/S1677-04202009000100005.

SOARES, L. A. et. al. Combinations of growth canopy - rootstock citrus under water stress under greenhouse conditions. Revista Brasileira de Engenharia Agrícola Environmental, v.19, n.3, p.211-217, 2015. Available from: <http://www.agriambi.com.br/ revista/v19n03/v19n03a03.pdf $>$. Accessed: Feb. 05, 2018. doi: 10.1590/1807-1929/agriambi.v19n3p211-217.

SOUZA, L. S.; PAIVA, A. Q. Variation of the total water potential in a tray toposequence soil for two years. Pesquisa agropecuária brasileira, v.36, no.2, p.349-355, 2001. Available from: <http:// seer.sct.embrapa.br/index.php/pab/article/view/6121/3188>. Accessed: Mar. 06, 2018.

VAN GENUCHTEN, M. T. A. The closed-form equation for predicting the hydraulic conductivity of unsaturated soils. Soil Science Society American Journal, 44: 892-897, 1980. Available from: <http://people.ucalgary.ca/ hayashi/glgy607/reading/van Genuchten1980.pdf>. Accessed: Jan. 05, 2017.

VEIHMEYER, V. J.; HENDRICKSON, A. H. Methods of measuring field capacity and wilting percentage of soils. Soil Science, v.68, p.75-94,1949. Available from: <https://journals.lww.com/soilsci/ Citation/1931/09000/THE_MOISTURE_EQUIVALENT_AS_A MEASURE OF THE FIELD.3.aspx $>$. Accessed: Jan. 08, $201 \overline{7}$. doi: 10.1097/00010694-194907000-00007. 